\title{
SEKTOR EKONOMI POTENSIAL DI KOTA PEKANBARU
}

\author{
Muklis, M.Rachmadi, dan Muslim
}

im_muklis@yahoo.com

\begin{abstract}
ABSTRAK
Tulisan ini bertujuan untuk mengidentifikasi sektor ekonomi potensial di kota Pekanbaru dengan data Produk Domestik Regional Bruto pada tahun 20102016 dimana tahun 2010 menjadi tahun dasar perhitungan. Metode yang digunakan adalah Analisis Location Quotient (LQ), Analisis Model Rasio Pertumbuhan (MRP) dan Analisis Shift-Share Modifikasi Estaban Marquillas (SS-EM). Berdasarkan analisis ini dapat diketahui subsektor ekonomi yang pontesial di kembangkan di kota pekanbaru adalah sebagai berikut: a.Kategori transportasi dan pergudangan, b.Kategori jasa keuangan, c.Kategori jasa perusahaan, d.Kategori jasa kesehatan dan sosial dan e.Kategori jasa lainnya.
\end{abstract}

Kata Kunci : Analisis Location Quotient (LQ), Analisis Model Rasio Pertumbuhan (MRP) dan Analisis Shift-Share Modifikasi Estaban Marquillas (SS-EM)

\subsection{Latar Belakang}

\section{BAB I. PENDAHULUAN}

Pembangunan ekonomi dapat diartikan secara luas mencakup perubahan pada tata susunan ekonomi masyarakat secara menyeluruh. Pertumbuhan ekonomi sebagai syarat keharusan selain itu harus ada perubahan pada komposisi produksi, perubahan pada alokasi sumber daya produksi diantara kategori-kategori ekonomi, perubahan pada pola distribusi kekayaan dan pendapatan, perubahan pada pola kerangka kelembagaan dan kehidupan masyara kat secara keseluruhan (Sumitro Djojohadikusumo,1995).

Pembangunan ekonomi tidak dapat dicapai semata-mata dengan menying kirkan hambatan yang menghalangi kemajuan ekonomi. Pendorong utama pertumbuhan ekonomi ialah upaya untuk berhemat (ekonomi), peningka tan pengetahuan atau penerapannya di bidang produksi, peningkatan jumlah modal atau sumber lain. Kondisi politik, psikologi, sosial dan budaya, merupakan syarat yang sama pentingnya dengan kondisi ekonomi.

Cairncross dalam Jhingan (2003) menyatakan pembangunan bukanlah sekedar masalah memiliki sejumlah besar uang atau semata-mata fenomena ekonomi, ia mencakup semua aspek perilaku masyarakat, penegak hukum dan ketertiban, kecermatan dalam hubungan bisnis, termasuk dengan instansi yang berkaitan dengan penerimaan Negara, hubungan antara keluarga, buta huruf, keakraban dengan peralatan mekanis dan sebagainya.

Syarat utama bagi pembangunan ekonomi adalah bahwa proses pertumbuhan harus bertumpu pada kemampuan perekonomian di dalam negeri. Hasrat untuk memperbaiki nasib dan prakarsa untuk menciptakan kemajuan material harus muncul dari negara itu sendiri. Pembangunan harus diprakarsai oleh negara dan tidak dapat dicangkok dari luar. 
Kekuatan luar semestinya merangsang dan membantu kekuatan nasional. Ia hanya bersifat mampu, tidak mengganti. Bantuan luar negeri hanya dapat mengawasi atau merangsang pembangunan dan tidak untuk mempertahankannya. Semangat untuk membangun harus datang dari dalam diri. Pembangunan tidak akan mungkin dapat dilaksanakan jika ia tidak berkenan dihati rakyat.

Syarat kedua berkaitan dengan usaha menghilangkan ketidaksempur naan pasar. Ketidaksempurnaan pasar menyebabkan immobilitas faktor dan menghambat ekspansi kategorial dan pembangunan. Untuk menghilang kannya, lembaga sosio-ekonomi harus diperbaiki dan diganti dengan yang lebih baik. Tujuan perekonomian dengan demikian adalah penggarapan secara maksimal dan penggunaan secara efisien sumber-sumber yang ada. Syarat yang pokok ialah mengusahakan adanya suatu perubahan radikal medan produksi, mendorong keluar dan tidak sekedar menolong ke suatu medan produksi.

Pencapaian keberhasilan pemba ngunan daerah melalui pembangunan ekonomi harus disesuaikan dengan kondisi dan potensi masing-masing daerah serta diperlukan perencanaan pembangunan yang terkoordinasi antar kategori, perencanaan pembangunan disini bertujuan untuk menganalisis secara menyeluruh tentang potensipotensi yang dimiliki oleh suatu daerah. Keterbatasan sumber daya di suatu daerah baik sumber daya alam, sumber daya manusia, sumber daya finansial maupun sumber daya lainnya merupakan masalah umum yang dihadapi oleh sebagian besar daerah untuk dapat menggerakkan seluruh perekonomian yang mampu sebagai penggerak utama untuk memacu laju pembangunan disuatu daerah.

Kehadiran undang-undang (UU) Nomor 22 tahun 1999 tentang Pemerintahan Daerah dan UU Nomor 25 Tahun 1999 tentang Perimbangan Keuangan antara Pemerintah Pusat dan Pemerintah Daerah telah menciptakan proses demokratisasi bagi daerah untuk pengambil keputusan dan menggali sumber pendapatan sendiri. Daerah tidak lagi sebagai komponen desen tralisasi administrasi dan otonomi birokrasi, tetapi sudah diberi kewenangan untuk mengatur urusan rumahtangganya sendiri. Saat ini pemerintah tidak hanya berperan sebagai pelaksana kebijakan pemerintah pusat seperti pada era sebelumnya, namun lebih berperan sebagai penentu kebijakan di daerahnya (Yuwono, 1999).

Undang-undang tersebut kemudian revisi menjadi Undang-Undang No. 32 Tahun 2004 tentang Pemerintahan Daerah dan Undang-Undang No. 33 Tahun 2004 tentang Perimbangan Keuangan antara Pemerintah Pusat dan Pemerintah Daerah, otonomi daerah dilaksanakan dengan memberikan kewenangan yang seluas-luasnya, nyata, dan bertanggung jawab kepada daerah secara proporsional yang diwujudkan dengan pengaturan, pembagian dan pemanfaatan sumberdaya nasional yang berkeadilan, serta perimbangan keuang an antara Pemerintah Pusat dan Pemerintah Daerah secara proporsional, demokratis, adil, dan transparan dengan memperhatikan potensi, kondisi dan kebutuhan daerah.

Kebijakan-kebijakan yang ditentukan tidak harus sama dengan kebijakan nasional atau kebijakan daerah lain karena kondisi perekonomian suatu daerah belum tentu sama dengan kondisi perekono mian nasional atau daerah lainnya. Dengan perkataan lain kebijakan yang diambil harus berdasarkan kondisi dan situasi daerah itu sendiri.

Pertumbuhan ekonomi merupakan salah satu unsur utama dalam pembangunan ekonomi regional dan mempunyai implikasi kebijakan yang cukup luas, walaupun disadari bahwa proses pembangunan bukan hanya ditentukan oleh faktor ekonomi seperti: sumberdaya alam, akumulasi modal, organisasi, kemajuan teknologi, pembagian 
kerja dan skala produksi tetapi juga faktor nonekonomi seperti: faktor sosial, faktor manusia, faktor politik dan administratif.

Pembahasan tentang struktur dan faktor penentu pertumbuhan ekonomi regional semakin meningkat dalam era otonomi, masing-masing daerah berlomba-lomba meningkatkan pertumbuhan ekonomi daerahnya. Hal ini sangat penting artinya bagi Pemerintah Daerah dalam menentukan upaya-upaya yang dapat dilakukan untuk mendorong pertumbuhan ekonomi di daerahnya (Sjafrizal, 2008). Pertumbuhan ekonomi dapat didefinisikan sebagai perkembangan kegiatan perekonomian yang menyebabkan barang dan jasa yang diproduksikan masyarakat bertambah.

Salah satu cara untuk menilai prestasi pertumbuhan ekonomi adalah melalui penghitungan Produk Domestik Bruto (PDB) menurut harga-harga yang berlaku dalam tahun dasar (Sukirno, 2004). Untuk tingkat daerah disebut Produk Domestik Regional Bruto (PDRB).

Laju pertumbuhan ekonomi kota Pekanbaru pada tahun 2010 berada pada level 6,71 persen. Pada tahun 2011 mengalami kenaikan pertumbuhan ekonomi yaitu sebesar 6,96 persen. Pada tahun 2012 laju pertumbuhan Provinsi Riau mencapai level 7,63 persen. Kemudian melambat laju pertumbuhannya apda tahun 2013 yaitu sebesar 7,11 persen. Kemudian pada tahun 2014 laju pertumbuhannya menjadi 7,32 persen.

Oleh karena itu, diperlukan kajian khusus untuk menentukan kategori-kategori ekonomi potensial yang ada di Kota Pekanbaru.

\subsection{Tujuan}

Berdasarkan Peraturan Pemerintah No.26 Tahun 2008 tentang Rencana Tata Ruang Wilayah Nasional yang mengamanatkan pembangunan berbasis kepulauan memberikan wawasan baru untuk operasionalisasi tata ruang wilayah nasional dalam wadah pulau/kepulauan. Pembangunan dalam kerangka otonomi daerah menyebabkan biaya pembangunan ditanggung oleh setiap daerah dimana tidak semua daerah mempunyai sumber daya yang berlimpah, sehingga ada beberapa daerah yang mempunyai dana terbatas untuk membangun daerahnya masing-masing. Hal penting yang harus dilakukan pemerintah daerah adalah kemampuan mengalokasikan dana yang ada untuk membangun perekonomian guna meningkatkan kesejahteraan masyarakat.

\subsection{Sumber Data}

Data yang digunakan dalam penelitian ini merupakan data sekunder yang bersumber dari Badan Pusat Statistik (BPS). Data yang tercakup dalam penelitian ini adalah data PDRB Kota Pekanbaru dan data PDRB Provinsi Riau Tahun 2010-2016 baik Atas Dasar Harga Berlaku maupun Atas Dasar Harga Konstan, disertai dengan data-data sekunder lain yang relevan dengan tujuan analisis ini.

\subsection{PDRB Tahun Dasar 2010}

PDRB Kota Pekanbaru yang sudah menggunakan tahun dasar 2010 (sudah tidak menggunakan PDRB tahun dasar 2000). PDRB tahun Dasar 2010 sudah mencakup impelmentasi Sistem Neraca Nasional (SNA) 2008. Klasifikasi PDRB menurut lapangan usaha tahun dasar 2010 menggunakan KBLI 2009.

\section{BAB II. KAJIAN LITERATUR \\ 2.1. Teori Basis Ekonomi dan Kategori Ekonomi Potensial}

Salah satu teori ekonomi yang dikembangkan dalam rangka meningkatkan perekonomian daerah adalah teori basis ekspor (atau teori basis ekonomi). Menurut Glasson (1990) kegiatan-kegiatan Basis (basic activities) adalah kegiatan mengekspor barang-barang dan jasa keluar batas perekonomian masyarakatnya atau memasarkan 
barang dan jasa mereka kepada orang yang dating dari luar perbatasan perekonomian masyarakat yang bersangkutan. Sedangkan kegiatan bukan basis (non basic activities) adalah kegiatan menyediakan barang yang dibutuhkan oleh orang yang bertempat tinggal didalam batas perekonomian masyarakat yang bersangkutan. Kegiatan-kegiatan ini tidak mengekspor barang jadi; luas lingkup produksi dan daerah pasar yang terutama bersifat lokal. Implisit didalam pembagian kegiatan-kegiatan ini terdapat hubungan sebab akibat yang membentuk teori basis ekonomi.

Daerah mempunyai kesempatan untuk mengembangkan sumber daya yang dimiliki dengan memanfaatkan tenaga kerja yang ada termasuk dari luar daerah dalam upaya meningkatkan peluang ekspor. Lebih lanjut dalam analisisnya, teori basis ekonomi biasanya menggunakan data PDRB untuk mengidentifikasi dan menentukan kategori potensial. Apabila kategori potensial tersebut dikembangkan dengan baik akan mempunyai pengaruh yang signifikan terhadap pertumbuhan ekonomi daerah, yang pada akhirnya dapat meningkatkan pendapatan daerah secara optimal.

Mengacu pada teori ekonomi basis tersebut maka Arsyad (2008) menjelaskan bahwa teknik Location Quotient dapat membagi kegiatan ekonomi suatu daerah menjadi dua golongan yaitu:

1. Kegiatan kategori ekonomi yang melayani pasar didaerah itu sendiri maupun di luar daerah yang bersangkutan. Kategori ekonomi seperti ini dinamakan kategori ekonomi potensial (basis);

2. Kegiatan kategori ekonomi yang hanya dapat melayani pasar di daerah itu sendiri dinamakan kategori ekonomi tidak potensial (non basis) atau local industry.

Menurut Syafrizal (2002), dalam kerangka teori basis ekspor ini, diketahui bahwa peningkatan ekspor terjadi apabila suatu daerah memiliki keuntungan kompetitif (competitive advantage) yang cukup besar pada beberapa kategori ekonomi. Dijelaskan pula bahwa dengan teori basis ekspor ini, bahwa untuk melihat besarnya keuntungan kompetitif perekonomian suatu daerah dapat dilakukan dengan penaksiran multiplier ekspor dan analisis shift share.

\subsection{Keunggulan Komparatif dan Keunggulan Kompetitif Wilayah}

Pada era otonomi daerah seperti sekarang ini, setiap daerah memiliki kebebasan dalam menentukan arah dan kebijakan pembangunan ekonomi wilayah. Untuk menentukan arah dan kebijakan pembangunan ekonomi di suatu daerah sangat diperlukan informasi mengenai potensi ekonomi wilayah. Potensi ekonomi wilayah dapat diketahui dengan mengidentifikasi keunggulan dan kelemahan berbagai kategori maupun subkategori ekonomi di wilayah tersebut. Kategori ekonomi yang memiliki keunggulan, memiliki prospek yang lebih baik untuk dikembangkan dan diharapkan dapat mendorong kategori-kategori ekonomi lain untuk berkembang. Keunggulan perekonomian wilayah tersebut secara garis besar terdiri atas keunggulan komparatif dan keunggulan kompetitif (daya saing).

Istilah keunggulan komparatif (comparative advantage) mula-mula dikemukakan oleh Ricardo (1973) terkait dengan bahasan perdagangan antar dua wilayah. Ricardo membuktikan bahwa bila dua wilayah yang saling berdagang masing-masing mengkonsentrasikan diri untuk mengekspor barang yang memiliki keunggulan komparatif, maka kedua wilayah tersebut akan mendapatkan keuntungan. Ide tersebut bukan saja bermanfaat dalam perdagangan internasional tetapi juga sangat penting diperhatikan dalam ekonomi regional.

Pengetahuan terhadap keunggulan komparatif suatu daerah dapat digunakan untuk mendorong perubahan struktur ekonomi daerah ke arah kategori yang mengandung 
keunggulan komparatif. Jadi, apabila kategori yang memiliki keunggulan komparatif bagi suatu daerah telah teridentifikasi maka pembangunan kategori tersebut dapat disegerakan tanpa menunggu tekanan mekanisme pasar yang sering berjalan terlambat (Tarigan, 2003).

Pada era perdagangan bebas seperti sekarang ini, keunggulan kompetitif mendapat perhatian lebih besar daripada keunggulan komparatif. Keunggulan kompetitif menunjukkan kemampuan daerah untuk memasarkan produknya ke luar daerah. Dalam analisis ekonomi regional, keunggulan kompetitif dimaknai sebagai kemam puan daya saing kegiatan ekonomi suatu daerah terhadap kegiatan ekonomi yang sama di daerah lainnya. Keunggulan kompetitif merupakan cermin dari keunggulan pertumbuhan ekonomi suatu wilayah terhadap wilayah lainnya yang dijadikan benchmark dalam suatu kurun waktu (Thoha, 2003).

Dalam kaitannya dengan keunggul an kompetitif, maka keunggulan komparatif suatu kegiatan ekonomi dapat dijadikan suatu pertanda awal bahwa kegiatan ekonomi tersebut punya prospek untuk juga memiliki keunggulan kompetitif. Jika suatu kate gori memiliki keunggulan komparatif karena besarnya potensi kategori tersebut maka kebijakan yang diprioritaskan bagi pengembangan kegiatan ekonomi tersebut dapat berimplikasi kepada terciptanya keung gulan kompetitif. Kegiatan ekonomi yang memiliki keunggulan komparatif sekaligus keunggulan kompetitif akan sangat menguntungkan perekonomian suatu wilayah.

Terkait dengan keunggulan komparatif dan keunggulan kompetitif, maka berdasarkan kegiatan ekonomi nya suatu wilayah dapat saja memiliki kedua jenis keunggulan tersebut secara bersama-sama. Hal ini sangat dipengaruhi oleh satu atau gabungan beberapa faktor berikut ini (Tarigan, 2003);

1. Memiliki potensi sumber daya alam.

2. Penguasaan masyarakat terhadap teknologi mutakhir dan keterampilanketerampilan khusus lainnya.

3. Aksesibilitas wilayah yang baik.

4. Memiliki market yang baik atau dekat dengan market.

5. Wilayah yang memiliki sentra-sentra produksi tertentu atau terdapatnya aglomerasi dari berbagai kegiatan ekonomi.

6. Ketersediaan buruh (tenaga kerja) yang cukup dan memiliki keterampilan baik dengan upah yang relatif rendah.

7. Mentalitas masyarakat yang baik untuk pembangunan: jujur, terbuka, bekerja keras, dapat diajak bekerja sama dan disiplin.

8. Kebijaksanaan pemerintah yang mendukung pada terciptanya keunggulan suatu kegiatan ekonomi wilayah .

\subsection{Spesialisasi Perekonomian}

Perekonomian suatu wilayah terspesialisasi jika suatu wilayah memprioritaskan pengembangan suatu kategori ekonomi melalui kebijakan yang mendukung kemajuan kategori tersebut (Muzamil, 2010). Pengembang an kategori prioritas tersebut dapat dilakukan melalui investasi dan peningkatan sumber daya manusia pada kategori tersebut. Spesialisasi dalam perekonomian merupakan hal penting dalam rangka memacu pertumbuhan ekonomi suatu wilayah. Dikatakan, jika suatu wilayah memiliki spesialisasi pada kategori tertentu maka wilayah tersebut akan memiliki keunggulan kompetitif dari spesialisasi kategori tersebut (Soepono, 1993). Menurut Samuelson dan Nordhaus (1995) dalam Hairul (2002) masyarakat dapat lebih efektif dan efisien jika terdapat pembagian kerja, yang membagi keseluruhan proses produksi menjadi unit-unit 
khusus yang terspesialisasi. Ekonomi spesialisasi telah memungkinkan terbentuknya jaringan perdagangan antarindividu dan antarnegara yang demikian luas, yang merupakan ciri dari suatu perekonomian maju. Adanya keterkaitan ekonomi (spesialisasi) antar daerah yang mendorong proses pertukaran sesuai kebutuhan masing-masing, akan memungkinkan bergerak nya perekonomian masing-masing daerah secara bersama-sama menuju proses pertumbuhan.

Beberapa ahli ekonomi mulai memperhitungkan efek spesialisasi terhadap perekonomian suatu wilayah. Menurut Kuncoro (2002), salah satu upaya yang dapat ditempuh untuk meningkatkan keterkaitan antar wilayah adalah melalui proses pertukaran komoditas antar daerah. Berbagai macam alat analisis telah dikembangkan untuk melihat tingkat spesialisasi regional. Marquillas dalam Soepono (1993) memodifikasi analisis shift share klasik dengan memasukkan efek alokasi untuk melihat spesialisasi suatu kategori dalam suatu wilayah. Selanjutnya Kim dalam Kuncoro (2002) mengembangkan indeks krugman untuk melihat spesialisasi regional di Amerika Serikat.

a. Produk Domestik Regional Bruto (PDRB) adalah keseluruhan nilai akhir barang dan jasa yang dihasilkan di suatu wilayah untuk kurun waktu tertentu.

b. Pertumbuhan Ekonomi adalah pertumbuhan dari nilai PDRB atas dasar harga konstan pada suatu periode tertentu yang dibandingkan terhadap nilai PDRB atas dasar harga konstan pada tahun sebelumnya.

c. Kontribusi Kategori adalah sumbangan (share) atau persentase dari nilai tambah tiap kategori terhadap total PDRB pada suatu periode waktu tertentu.

d. Pendapatan Perkapita adalah total PDRB setelah dikurangi dengan penyusutan dan pajak tak langsung netto dibagi jumlah penduduk.

e. Kategori ekonomi potensial merupakan kategori ekonomi yang memiliki kriteria keunggulan komparatif, keunggulan kompetitif dan spesialisasi baik kontribusi maupun nilai rasio pertumbuhan yang baik jika dibandingkan dengan kategori ekonomi yang sama pada wilayah yang lebih luas baik dari sisi penciptaan nilai tambah maupun dari sisi penyerapan tenaga kerja.

f. Keunggulan komparatif mengacu pada kegiatan ekonomi suatu daerah yang menurut perbandingan lebih menguntungkan bagi perekonomian daerah tersebut. Perbandingan tersebut merupakan perbandingan kontribusi nilai tambah maupun tenaga kerja di kategori ekonomi suatu daerah yang lebih besar dibandingkan dengan daerah lainnya.

\subsection{Analisis Kategori Ekonomi Potensial}

\section{BAB III. METODOLOGI}

Secara garis besar, analisis kategori dan subkategori ekonomi potensial dalam penelitian ini dilakukan dengan mengidentifikasi kategori dan subkategori ekonomi potensial dari sisi kontribusi PDRB (aspek keunggulan komparatif) melalui alat analisis location quotient $(L Q)$ serta penentuan kategori dan subkategori ekonomi potensial dari sisi pertumbuhan PDRB (aspek keunggulan kompetitif) melalui alat analisis MRP dan analisis Shift-Share Estaban Marquillas (SS-EM). Khusus mengenai identifikasi dan pengaruh spesialisasi perekonomian wilayah akan dijelaskan melalui analisis Shift-Share Estaban Marquillas.

Selanjutnya setelah aspek keunggulan komparatif, keunggulan kompetitif dan spesialisasi teriden tifikasi, maka dilakukan analisis overlay yang bertujuan untuk melihat potensi kategori dan subkategori ekonomi di Kota Pekanbaru berdasar kan gabungan dari ketiga alat analisis tersebut. 


\section{a. Analisis Location Quotient (LQ)}

Analisis Location Quotient digunakan untuk menunjukkan besar kecilnya peranan kategori perekonomi an suatu region dengan membanding kan kategori yang sama pada wilayah yang lebih besar. Metode ini digunakan untuk mengidentifikasi kategori ekonomi potensial yang menjadi unggulan yang dapat dikembangkan pada suatu wilayah dan dipergunakan untuk mengidentifikasi keunggulan komparatif (comparative advantage) suatu wilayah (Thoha dan Soekarni, 2000).

Penelitian ini menggunakan metode yang mengacu pada formulasi yang dikemukakan oleh Arsyad (1999).

Rumus $L Q$ yang digunakan adalah sebagai berikut:

$$
L Q_{i j}=\frac{x_{i j} / x_{i}}{X_{j} / X}
$$

dimana:

$L Q_{\mathrm{ij}}=$ Indeks $L Q$ kategori i Kota Pekanbaru

$\mathrm{x}_{\mathrm{ij}} \quad=$ PDRB ADHK kategori i Kota Pekanbaru

$\mathrm{x}_{\mathrm{i}}=$ Total PDRB ADHK Kota Pekanbaru

$\mathrm{x}_{\mathrm{j}}=$ Total PDRB ADHK kategori i Provinsi Riau

$\mathrm{x} \quad=$ Total PDRB ADHK Provinsi Riau

Kriteria pengukuran model tersebut yaitu;

a) Jika nilai $L Q>1$, berarti kategori tersebut merupakan kategori potensial, yang menunjukkan suatu kategori mampu melayani pasar baik di dalam maupun di luar Kota Pekanbaru.

b) Jika nilai $L Q<1$, berarti kategori tersebut bukan merupakan kategori potensial, yang menunjukkan suatu kategori belum mampu melayani pasar di baik di dalam maupun di luar Kota Pekanbaru.

c) Jika nilai $L Q=1$, berarti suatu kategori hanya mampu melayani pasar di Kota Pekanbaru saja atau belum dapat memasarkan hasil kategori tersebut ke luar daerah lain.

Dengan demikian dapat disimpulkan bahwa apabila $L Q>1$, berarti kategori tersebut merupakan kategori unggulan di daerah dan potensial untuk dikembangkan sebagai penggerak perekonomian daerah. Begitupun sebaliknya bila nilai $L Q<1$, berarti kategori tersebut bukan merupakan kategori unggulan di daerah dan kurang potensial untuk dikembangkan sebagai penggerak perekonomian daerah.

\section{b. Analisis Model Rasio Pertumbuhan (MRP)}

Selain alat analisis $L Q$ yang digunakan untuk mengidentifikasi kategori dan subkategori ekonomi potensial berdasarkan kriteria kontribusi PDRB, alat analisis lain dirasa kan penting dipergunakan untuk mengidentifikasi kategori dan subkategori ekonomi potensial di Kota Pekanbaru. Hal ini mengacu kepada rekomendasi Yusuf (1999), yang menganjurkan untuk menggunakan lebih dari satu alat analisis dalam mengidentifikasi kategori ekonomi potensial di suatu wilayah. Oleh karena itu, analisis MRP turut digunakan untuk menganalisis kategori dan subkategori ekonomi potensial berdasarkan kriteria pertumbuhan Kota Pekanbaru.

MRP adalah kegiatan membanding kan pertumbuhan suatu kegiatan baik dalam skala yang lebih kecil maupun dalam skala yang lebih luas. Dalam analisis MRP terdapat dua macam rasio pertumbuhan, yaitu:

1. Rasio pertumbuhan wilayah studi (RPs) merupakan perbandingan antara 
pertumbuhan pendapatan (PDRB) kategori i di Kota Pekanba ru dengan pertumbuhan pendapat an (PDRB) kategori i di Provinsi Riau.

2. Rasio pertumbuhan wilayah referen si (RPr) perbandingan rata-rata pertumbuhan pendapatan (PDRB) kategori i di Kota Pekanbaru dengan rata-rata pertumbuhan pendapatan (PDRB) di Provinsi Riau.

Analisis MRP ini merupakan modifikasi dari komponen proportional shift dan differential shift dalam analisis shift-share (Yusuf, 1999). Komponen proportional shift dan differential shift yang dalam analisis shift-share Estaban Marquillas disimbolkan dengan Mij dan Cij ini memberikan nilai perubahan baik pengurangan maupun penambahan PDRB. Dengan demikian, Mij dan Cij menunjukkan perubahan nilai yang besar (bukan rasio). Melalui modifikasi maka akan didapat nilai yang lebih besar, lebih kecil atau sama dengan 1 (rasio).

Formulasi dari RPs dan RPr yang merupakan penurunan dari persamaan sebagai berikut (Yusuf, 1999):

1. Rasio Pertumbuhan Wilayah Referensi (RPr):

$$
\begin{aligned}
& M_{i j}=\left[\frac{\Delta E_{i n}}{E_{i n}}-\frac{\Delta E_{n}}{E_{n}}\right] E_{i j} \\
& \frac{M_{i j}}{E_{i j}}=\left[\frac{\Delta E_{i n} E_{n}}{E_{i n} E_{n}}-\frac{\Delta E_{n} E_{i n}}{E_{i n} E_{n}}\right] \\
& \frac{M_{i j}}{E_{i j}}=\left[\frac{\Delta E_{i n} E_{n}}{E_{i n} \Delta E_{n}}-1\right] \frac{\Delta E_{n}}{E_{n}} \\
& \frac{E_{n} M_{i j}}{\Delta E_{n} E_{i j}}+1=\frac{\Delta E_{i n} E_{n}}{E_{i n} \Delta E_{n}}=\frac{\Delta E_{i n} / E_{i n}}{\Delta E_{n} / E_{n}} \ldots \ldots .
\end{aligned}
$$

Rasio Pertumbuhan Wilayah Referensi (RPr) $=\frac{\Delta E_{\text {in }} / E_{\text {in }}}{\Delta E_{n} / E_{n}}$

2. Rasio Pertumbuhan Wilayah Studi (RPs) :

$$
\begin{aligned}
& C_{i j}=\left[\frac{\Delta E_{i j}}{E_{i j}}-\frac{\Delta E_{i n}}{E_{i n}}\right] E_{i j} \\
& C_{i j}=\Delta E_{i j}-\frac{\Delta E_{i n} E_{i j}}{E_{i n}} \\
& C_{i j}=\left[\frac{\Delta E_{i j} E_{i n}}{\Delta E_{i n} \Delta E_{i j}}-1\right] \frac{\Delta E_{i n} E_{i j}}{E_{i n}} \\
& \frac{E_{i n} C_{i j}}{\Delta E_{i n} E_{i j}}+1=\frac{\Delta E_{i j} E_{i n}}{E_{i n} \Delta E_{i j}}=\frac{\Delta E_{i j} / E_{i j}}{\Delta E_{i n} / E_{i n}}
\end{aligned}
$$

Rasio Pertumbuhan Wilayah Studi (RPs) $=\frac{\Delta E_{i j} / E_{i j}}{\Delta E_{i n} / E_{\text {in }}}$

Dimana :

$\Delta E_{i j}=E_{i j, t}-E_{i j}$

$\Delta E_{\text {in }}=E_{\text {in }, t}-E_{\text {in }}$

$\Delta E_{n}=E_{n, t}-E_{n}$

Keterangan :

$\Delta \mathrm{E}_{\mathrm{ij}}$ : Perubahan PDRB kategori (subkategori) $i$ di Kota Pekanbaru 
$\mathrm{E}_{\mathrm{ij}, \mathrm{t}}$ : PDRB kategori (subkategori) $i$ di Kota Pekanbaru pada tahun akhir analisis

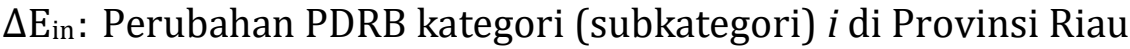

$E_{i n, t}$ : PDRB kategori (subkategori) $i$ di Provinsi Riau pada tahun akhir analisis

$\Delta \mathrm{E}_{\mathrm{n}}$ : Perubahan PDRB di Provinsi Riau

$E_{n, t}$ : Total PDRB tahun akhir analisis di Provinsi Riau

$\mathrm{M}_{\mathrm{ij}}$ : Perubahan PDRB kategori (subkategori) $i$ di Kota Pekanbaru yang disebabkan oleh pengaruh pertumbuhan kategori (subkategori) $i$ di Provinsi Riau.

$\mathrm{C}_{\mathrm{ij}} \quad$ : Perubahan PDRB kategori (subkategori) $i$ di Kota Pekanbaru yang disebabkan oleh keunggulan kompetitif kategori (subkategori) $i$ di Provinsi Riau.

\section{c. Analisis Shift-Share (SS)}

Untuk dapat mengidentifikasi keunggulan daerahnya dan menganali sis industri/kategori yang menjadi dasar perekonomian daerah maka digunakan teknik analisis shift-share. Analisis shift-share juga merupakan suatu analisis yang dilakukan untuk mengetahui perubahan dan pergeseran kategori atau industri pada perekono mian regional maupun lokal. Analisis shift-share menggambarkan kinerja kategori-kategori di suatu wilayah dibandingkan dengan perekonomian nasional. Bila suatu daerah memperoleh kemajuan sesuai dengan kedudukannya dalam perekonomian nasional, maka akan dapat ditemukan adanya shift (pergeseran) hasil pembangunan perekonomian daerah.

Selain itu, laju pertumbuhan kategori-kategori di suatu wilayah akan dibandingkan dengan laju pertumbuhan perekonomian nasional beserta kategori-kategorinya. Kemudian dilakukan analisis terhadap penyimpang an yang terjadi sebagai hasil dari perbandingan tersebut. Bila penyimpangan itu positif, hal itu disebut keunggulan kompetitif dari suatu kategori dalam wilayah tersebut. (Soepono, 1993:44).

Metode analisis shift-share diawali dengan mengukur perubahan nilai tambah bruto atau PDRB suatu kategori-i di suatu region-j (Dij) dengan for mulasi (Soepono, 1993):

$\mathrm{Dij}=\mathrm{Nij}+\mathrm{Mij}+\mathrm{Cij}$

di mana:

$$
\begin{aligned}
& \mathrm{Nij}=\text { Eij. rn } \\
& \mathrm{Mij}=\text { Eij (rin - rn) }
\end{aligned}
$$

$\mathrm{Cij}=\mathrm{Eij}(\mathrm{rij}-\mathrm{rin})$

Dari persamaan (16) sampai (18), rij mewakili pertumbuhan kategori/ subkategorii di kota Pekanbaru, sedangkan rn dan rin masing-masing laju pertumbuhan agregat Provinsi Riau dan pertumbuhan kategori/ subkategori i Provinsi Riau.

Masing-masing laju pertumbuhan didefinisikan sebagai berikut.

1. Mengukur laju pertumbuhan kategori i diwilayah Kota Pekanbaru $\mathrm{rij}=(\mathrm{Eij}, \mathrm{t}-\mathrm{Eij}) / \mathrm{Eij}$

2. Mengukur laju pertumbuhan kategori i perekonomian Provinsi Riau rin $=($ Ein,$t-$ Ein $) /$ Ein

3. Mengukur laju pertumbuhan perekonomian di Provinsi Riau

$$
\mathrm{rn}=(\mathrm{En}, \mathrm{t}-\mathrm{En}) / \mathrm{En}
$$

Keterangan;

Di,j : Perubahan PDRB kategori (subkategori) i di Provinsi Riau

Ni,j : Perubahan PDRB kategori (subkategori) i di Kota Pekanbaru yang disebabkan oleh pengaruh pertumbuhan ekonomi Provinsi Riau.

Mi,j : Perubahan PDRB kategori (subkategori) i di Kota Pekanbaru yang disebabkan oleh pengaruh pertumbuhan kategori (subkategori) i Provinsi Riau

Ci,j : Perubahan PDRB kategori (subkategori) i di Kota Pekanbaru yang disebabkan oleh 
keunggulan kompetitif kategori (subkategori) tersebut di Provinsi Riau. Eij : PDRB kategori i di Kota Pekanbaru tahun awal analisis

Ein : PDRB kategori i di Provinsi Riau tahun awal analisis

En : PDRB total di Provinsi Riau tahun awal analisis

Eij,t: PDRB kategori i di Kota Pekanbaru tahun akhir analisis

Ein,t: PDRB kategori i di Provinsi Riau tahun akhir analisis

En,t : PDRB total di Provinsi tahun akhir analisis

Persamaan (19) sampai (21) juga menunjukkan bahwa peningkatan nilai tambah suatu kategori di Kota Pekanbaru (Dij) dapat diuraikan (decompose) menjadi 3 faktor berpengaruh, yaitu (Syafrizal, 2008):

a. Regional Share (Nij) adalah komponen pertumbuhan ekonomi daerah yang disebabkan oleh faktor luar yaitu; peningkatan kegiatan ekonomi daerah akibat kebijaksanaan nasional atau provinsi yang berlaku pada seluruh daerah.

b. Proportional Shift (Mij) adalah komponen pertumbuhan ekonomi daerah yang disebabkan oleh struktur ekonomi daerah yang baik, yaitu berspesialisasi pada kategori yang pertumbuhannya cepat secara nasional atau provinsi.

c. Differential Shift (Cij) adalah komponen pertumbuhan ekonomi daerah karena kondisi spesifik daerah yang bersifat kompetitif. Unsur pertumbuhan ini merupakan keuntungan kompetitif daerah yang dapat mendorong pertumbuhan ekspor daerah.

Melalui ketiga komponen tersebut dapat diketahui komponen atau unsur pertumbuhan mana yang mempengaruhi pertumbuhan ekonomi daerah. Nilai masingmasing komponen dapat saja negatif atau positif, tetapi jumlah keseluruhan akan selalu positif, bila pertumbuhan ekonomi juga positif dan begitu pula sebaliknya. Berdasarkan persamaan (2) sampai (8) di atas, maka dampak bauran industri (industrial mix) dan keunggulan kompetitif dapat ditentukan bagi suatu kategori-i atau dijumlahkan untuk semua kategori sebagai keseluruhan wilayah. Persamaan Shift-Share untuk kategori-i di wilayah-j adalah:

Dij=Eij.rn+Eij(rin-rn)+Eij(rij-rin) .....(22)

Selanjutnya menurut Oppenheim dalam Yusuf (1999), analisis pertumbuhan ekonomi regional komponen proportional shift (PS) dan differential shift (DS) lebih penting dibanding komponen regional share. Hal ini karena DS digunakan untuk melihat perubahan pertumbuhan dari suatu kegiatan di wilayah studi terhadap kegiatan tersebut di wilayah referensi. Dari perubahan tersebut dapat dilihat berapa besar pertambahan atau pengurangan pendapatan dari kegiatan tersebut. Sedangkan PS untuk melihat perubahan pertumbuhan suatu kegiatan di wilayah referensi terhadap kegiatan total (PDRB) di wilayah referensi.

Dari kedua komponen ini jika besaran PS dan DS dinyatakan dalam suatu bidang datar, dengan nilai PS sebagai sumbu horisontal dan nilai DS sebagai sumbu vertikal, akan diperoleh empat kategori posisi relatif dari seluruh daerah atau kategori ekonomi tersebut. Keempat kategori tersebut adalah (dalam Freddy, 2001):

- Kategori I (PS positif dan DS positif) adalah wilayah/kategori dengan pertumbuhan sangat pesat (rapid growth region).

- Kategori II (PS negatif dan DS positif) adalah wilayah/kategori dengan kecepatan pertumbuhan terhambat tapi berkembang (depressed region yang berkembang).

- Kategori III (PS positif dan DS negatif) adalah wilayah/kategori dengan kecepatan pertumbuhan terhambat namun cenderung berpotensi (depressed region yang berpotensi). 
- Kategori IV (PS negatif dan DS negatif) adalah wilayah/kategori depressed region dengan daya saing lemah dan juga peranan terhadap wilayah rendah.

\section{Modifikasi Estaban-Marquillas (E-M) terhadap Analisis Shift-share Klasik}

Selanjutnya untuk mengetahui tingkat spesialisasi perekonomian di suatu daerah dapat dilakukan dengan modifikasi analisis shift-share yang dilakukan oleh EstabanMarquillas (1972). Estaban Marguillas pada tahun 1972 telah melakukan modifikasi terhadap teknik analisis Shift-share untuk memecahkan masalah pengaruh efek alokasi dan spesialisasi (Soepono, 1993). Dengan mengacu kepada persamaan di atas, maka modifikasi persamaan Shift-Share menurut Estaban Marguillas mengandung unsur baru yang diberi notasi $E^{*}$ ij didefinisikan sebagai suatu variabel wilayah (Eij), bila struktur wilayah sama dengan struktur nasional atau $E \mathrm{ij}=\mathrm{E}^{*} \mathrm{ij}$ maka $\mathrm{E}^{*} \mathrm{ij}$ dirumuskan menjadi: $\mathrm{E}^{*} \mathrm{ij}=\mathrm{Ej}(\mathrm{Ein} / \mathrm{En})$

Apabila Eij diganti dengan $\mathrm{E}^{*} \mathrm{ij}$ maka persamaan $\mathrm{Cij}=\mathrm{Eij}(\mathrm{rij}$ - rin) dapat pula diganti menjadi:

$\mathrm{C}^{*} \mathrm{ij}=\mathrm{E}^{*} \mathrm{ij}(\mathrm{rij}-\mathrm{rin})$

Cij adalah untuk mengukur keunggulan atau ketidakunggulan kompetitif di kategori-i pada perekonomian suatu wilayah menurut analisis Shift-share klasik. Pengaruh efek alokasi (allocation effect) belum dijelaskan dari suatu variabel wilayah untuk kategori-i di wilayah j (Aij), untuk mengetahui efek alokasi tersebut didekati dengan menggunakan rumus (Soepono, 1993):

$A i j=\left(E i j-E^{*} i j\right)(r i j-r i n)$ dimana:

Aij : Pengaruh alokasi dibagi menjadi dua bagian yaitu adanya tingkat spesialisasi kategori $i$ di Kota Pekanbaru dikalikan dengan keunggulan kompetitif.

(Eij-E*ij): menggambarkan tingkat spesialisasi kategori $i$ di Kota Pekanbaru, jika Eij> $E^{*} \mathrm{ij}$

(rij-rin) : menggambarkan tingkat keunggulan kompetitif kategori $i$ di Kota Pekanbaru, jika rij>rin

Dari uraian di atas dapat disimpulkan bahwa Aij sebagai pengaruh alokasi dapat dilihat dalam dua bagian yaitu tingkat spesialisasi kategori i di wilayah j (Eij - E*ij) yang dikalikan dengan keunggulan kompetitif ( rij - rin). Persamaan tersebut dapat bermakna bahwa bila suatu wilayah mempunyai suatu spesialisasi di kategori tertentu, maka kategori tersebut pasti akan menikmati pula keunggulan kompetitif yang lebih baik.

Kemungkinan-kemungkinan yang akan terjadi dari efek alokasi akan dijelaskan pada Tabel 3.1. Dari hasil modifikasi Estaban-Marquillas terhadap analisis Shift-Share dapat dirumuskan sebagai berikut (Soepono, 1993):

$D_{i j}=E_{i j}\left(r_{n}\right)+E_{i j}\left(r_{i n}-r_{n}\right)+E_{i j}^{*}\left(r_{i n}-r_{n}\right)+\left(E_{i j}-E_{i j}^{*}\right)\left(r_{i n}-r_{n}\right)$

\section{Tabel III.1. Kemungkinan hasil perhitungan dari Efek Alokasi}

\section{d. Analisis Overlay}

Setelah melakukan analisis Location Quotient $(L Q)$ dan Model Rasio Pertumbuhan (MRP), analisis dilanjutkan dengan menggunakan analisis overlay yang bertujuan untuk memperoleh deskripsi kegiatan ekonomi unggulan dalam suatu wilayah yang didasarkan atas kriteria pertumbuhan (hasil analisis wilayah studi atau RPs) dan kriteria kontribusi 
(hasil analisis $L Q$ ) baik berdasarkan penciptaan nilai tambah maupun penyerapan tenaga kerja. Dari analisis ini terdapat empat kemungkinan yaitu kombinasi antara kategori ekonomi unggulan yang menggambarkan keadaan suatu daerah sebagai berikut:

1. Pertumbuhan (+) dan kontribusi (+) menunjukkan suatu kategori (subkategori) yang sangat dominan baik dari pertumbuhan maupun dari kontribusinya.

2. Pertumbuhan (+) dan kontribusi (-) menunjukkan suatu kategori (subkategori)

\begin{tabular}{|c|c|c|c|c|}
\hline No. & rij-rin & Eij-E*ij & $\begin{array}{c}\text { Keunggulan } \\
\text { Kompetitif }\end{array}$ & $\begin{array}{c}\text { Spesia } \\
\text { lisasi }\end{array}$ \\
\hline 1 & $>0$ & $>0$ & $\sqrt{ }$ & $\sqrt{ }$ \\
2 & $>0$ & $<0$ & $\sqrt{ }$ & $\mathrm{x}$ \\
3 & $<0$ & $>0$ & $\mathrm{x}$ & $\sqrt{ }$ \\
4 & $<0$ & $<0$ & $\mathrm{x}$ & $\mathrm{X}$ \\
\hline
\end{tabular}
yang pertumbuhannya dominan tetapi kontribusinya kecil.

3. Pertumbuhan (-) dan kontribusi (+) menunjukkan suatu kategori (subkategori) yang pertumbuhannya kecil tetapi kontribusinya besar.

4. Pertumbuhan (-) dan kontribusi (-) menunjukkan suatu kategori (subkategori) yang tidak potensial baik kriteria pertumbuhan maupun kontribusinya.

Namun analisis overlay tersebut belum mengakomodasi hasil analisis SS $\neg$ EM yang merepresentasikan keunggulan kompetitif dan spesialisasi perekonomian suatu wilayah. Sebagaimana yang pernah dilakukan Saimima (2003), analisis overlay digunakan dengan pertimbangan memasukkan hasil analisis SS-EM, sehingga akan diperoleh deskripsi kegiatan ekonomi potensial suatu wilayah berdasarkan rasio pertumbuhan wilayah studi, keunggulan komparatif, keunggulan kompetitif serta spesialisasi.

\section{e. Analisis Pola dan Struktur Pertumbuhan Ekonomi Regional}

Gambaran tentang pola dan struktur pertumbuhan ekonomi di Kota Pekanbaru dapat diketahui dengan mengggunakan analisis Klassen Tipology. Kemudian untuk melihat pola dan struktur pertumbuhan berdasarkan sektor dan subsektor ekonomi di Kota Pekanbaru dilakukan melalui pendekatan modifikasi analisis Klassen Tipology. Analisis ini dilakukan dengan melihat pertumbuhan dan kontribusi masing-masing sektor dan subsektor ekonomi di Kota Pekanbaru dengan dibandingkan terhadap pertumbuhan dan kontribusi sektor maupun subsektor ekonomi yang sama pada tingkat Provinsi Riau. Penggunaan dan interprestasi alat analisis ini dapat dilihat pada Tabel III.2.

Tabel III.2. Klasifikasi Pertumbuhan Sektor (Subsektor) Ekonomi Menurut Klassen Typology

\begin{tabular}{|l|l|l|}
\hline $\begin{array}{l}\text { Kontribusi } \\
\text { (p) } \\
\text { Laju } \\
\text { Pertumbuh } \\
\text { an (r) }\end{array}$ & pi $>\mathrm{p}$ & $\mathrm{pi}<\mathrm{p}$ \\
\hline $\mathrm{ri}>\mathrm{r}$ & $\begin{array}{l}\text { Kuadran I } \\
\text { Kategori } \\
\text { Maju dan } \\
\text { cepat } \\
\text { tumbuh }\end{array}$ & $\begin{array}{l}\text { Kuadran III } \\
\text { Kategori } \\
\text { Berkembang } \\
\text { dengan pesat }\end{array}$ \\
\hline $\mathrm{ri}<\mathrm{r}$ & $\begin{array}{l}\text { Kuadran II } \\
\text { Kategori } \\
\text { Maju tapi } \\
\text { tertekan }\end{array}$ & $\begin{array}{l}\text { Kuadran IV } \\
\text { Kategori } \\
\text { Relatif } \\
\text { tertinggal }\end{array}$ \\
\hline
\end{tabular}

Sumber : Apriliyanto (2003)

Keterangan :

ri : Rata-rata laju pertumbuhan PDRB sektoral Kota Pekanbaru 
$r \quad$ : Rata-rata laju pertumbuhan PDRB sektoral Provinsi Riau

pi : Rata-rata kontribusi PDRB sektoral Kota Pekanbaru

p : Rata-rata kontribusi PDRB sektoral Provinsi Riau

\subsection{Analisis Kategori Ekonomi Potensial Kota Pekanbaru}

Untuk mengidentifikasi dan menganalisa kategori/subkategori eko nomi yang potensial di Kota Pekanbaru akan digunakan 3 macam alat analisis, yaitu Analisis Location Quotient ( $L Q$ ), Analisis Model Rasio Pertumbuhan (MRP) dan Analisis ShiftShare Modifikasi Estaban Marquillas (SS-EM). Secara lebih rinci pembahasan melalui ketiga alat analisis tersebut akan dijelaskan berikut ini.

\subsubsection{Analisis Location Quotient}

Alat analisis Location Quotient $(L Q)$ ini digunakan untuk mengiden tifikasi keunggulan komparatif kegiatan ekonomi (biasa disebut juga sebagai kategori basis) di Kota Pekanbaru dengan membandingkannya terhadap Provinsi Riau. Berdasarkan analisis $L Q$ sebagaimana yang tertera pada Grafik IV.1 maka Kota Pekanbaru terdapat 15 kategori ekonomi yang memiliki keunggulan komparatif (nilai $L Q$-nya $>1$ ), yaitu: kategori listrik dan gas, kategori pengadaan air, kategori konstruksi, kategori perdagangan dan perawatan mobil dan sepeda motor, kategori transportasi, kategori akomoda si dan restoran,kategori infokom, kategori jasa keuangan,kategori real estate, kategori jasa perusahaan, kategori pemerintahan, kategori jasa pendidikan, kategori jasa kesehatan dan sosial dan kategori jasa lainnya.

\section{Grafik IV.1 Hasil Perhitungan Rata-rata $L Q$ Kota Pekanbaru dari Tahun 2010-2016}

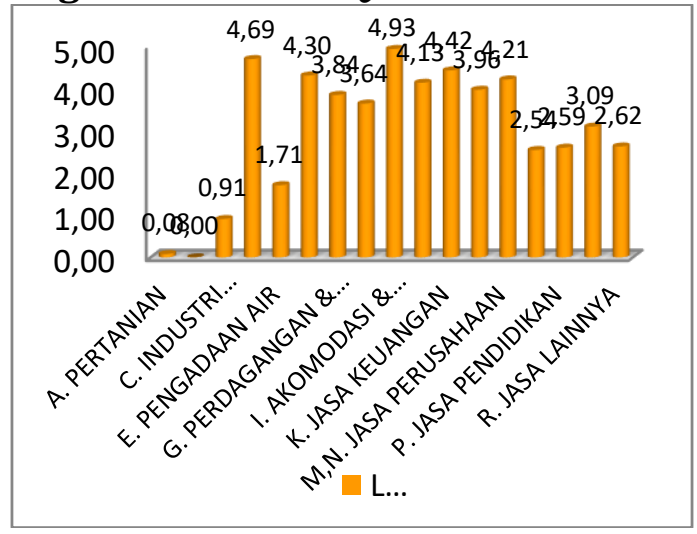

\subsubsection{Analisis Model Rasio Pertumbuhan}

Model Rasio Pertumbuhan (MRP) merupakan alat analisis yang digunakan untuk melihat potensi kategori ekonomi berdasarkan kriteria pertumbuhan. Menurut Yusuf (1999), analisis MRP terdiri atas 2 instrumen pengukuran yaitu Rasio Pertumbuhan Wilayah Studi (RPs) yang menunjukkan rasio pertumbuhan antara wilayah studi dengan wilayah referensi yang lebih besar, dalam hal ini adalah Kota Pekanbaru terhadap Provinsi Riau. Selanjutnya instrument kedua adalah Rasio Pertumbuhan Wilayah Referensi terhadap pertumbuhan ekonomi agregat pada wilayah referensi.

Grafik IV.2 memperlihatkan bahwa RPs kategori pertanian di Kota Pekanbaru memiliki nilai kurang dari 1 . Kondisi ini mengindikasikan bahwa kategori pertanian bukan merupakan kegiatan ekonomi yang potensial di Kota Pekanbaru berdasarkan kriteria pertumbuhan. Untuk Provinsi Riau kategori pertanian merupakan kategori yang 
potensial, karena memiliki nilai RPr yang lebih dari 1. Hal ini menunjukkan bahwa kategori pertanian tetap kategori yang potensial.

Kategori pertambangan dan penggalian di Kota Pekanbaru juga ternyata memiliki nilai RPs kurang dari 1, yang berarti kategori ini bukan merupakan kategori yang potensial berdasarkan kriteria pertumbuhan. Kondisi ini juga sama jika dibandingkan dengan Provinsi riau, karena nilai RPr kategori pertambangan dan penggalian (bukan migas) justru menunjukkan nilai negatif. Dengan demikian kategori pertambangan dan penggalian secara keseluruhan di Provinsi Riau juga kurang potensial dari sisi pertumbuhannya.

\section{Grafik IV.2 Hasil Perhitungan RPr dan RPs Kota Pekanbaru Tahun 2010-2016}

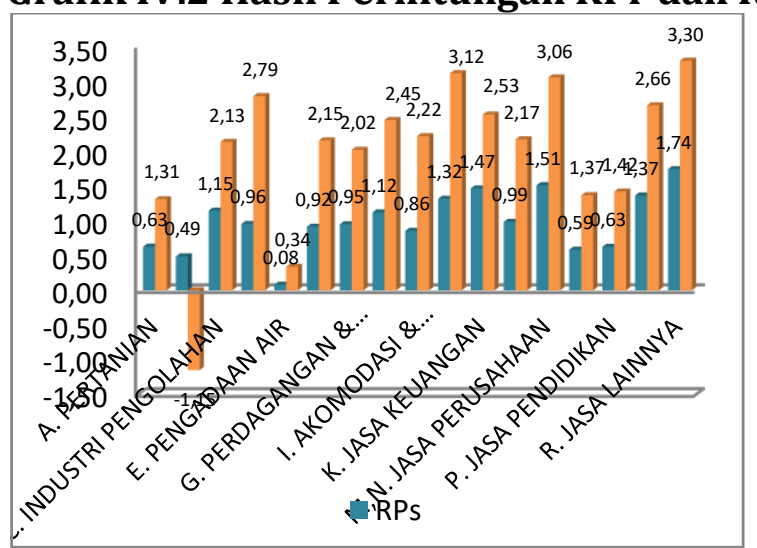

Selanjutnya kategori industri pengolahan merupakan kategori yang potensial di Kota Pekanbaru (RPs $=1,15)$. Begitu juga dengan Provinsi Riau, kategori ini merupakan kategori yang potensial $(\mathrm{RPr}=2,13)$.

Kategori pengadaan listrik dan gas di Provinsi Riau juga merupakan salah satu kategori yang kurang potensial jika dilihat dari nilai RPs-nya. Dilihat secara keseluruhan wilayah Riau, kategori listrik dan gas berpotensial dari sisi pertumbuhan, dengan nilai RPr sebesar 2,79.

Kategori pengadaan air di Kota Pekanbaru juga kurang berpotensial (RPs $=0,06$ ) dari sisi pertumbuhan, begitu juga dengan pertumbuhan kategori pengadaan air di Provinsi Riau kurang berpotensi (RPr $=0,34)$.

Kategori konstruksi di Kota Pekanbaru merupakan kategori yang kurang potensial $(\mathrm{RPs}=0,92)$ dari sisi pertumbuhan, berlawanan dengan pertumbuhan kategori konstruksi di Provinsi Riau merupakan kategori yang potensial dengan nilai RPr sebesar 2,15 .

Adapun Kategori perdagangan besar dan eceran, dan reparasi mobil dan sepeda motor juga kurang potensial di Kota Pekanbaru dengan RPs sebesar 0,95. Potensi kategori perdagangan besar dan eceran, dan reparasi mobil dan sepeda motor di Provinsi Riau cukup berpotensial (RPr> 1).

Selanjutnya kategori transportasi dan pergudangan di Provinsi Riau juga berpotensial dimana nilai RPs-nya sebesar 1,12. Sementara untuk Riau kategori transportasi dan pergudangan potensial $(\mathrm{RPr}=2,45)$.

Kategori penyediaan akomodasi dan makan minum di Kota Pekanbaru kurang potensial (RPs $=0,86)$. Di wilayah Riau kategori ini justru berpotensial (RPs $=2,22$ ).

Kategori Informasi dan Komunikasi di Kota Pekanbaru cukup potensial (RPs = 1,32) sedangkan di Provinsi Riau sangat potensial (RPs = 1,32). 
Kategori Jasa Keuangan di Kota Pekanbaru sangat potensial (RPs $=1,47$ ). Sebaliknya di Provinsi Riau kategori ini juga sangat potensial $(\operatorname{RPr}=2,53)$.

Kategori real estate kurang potensial juga $(\mathrm{RPs}=0,99)$ sedangkan di Provinsi Riau sangat potensial $(\mathrm{RPr}=2,17)$. Kategori jasa perusahaan sangat potensial $(\mathrm{RPs}=1,51)$ sejalan dengan di wilayah Riau yang sangat potensial $(\operatorname{RPr}=3,06)$.

Kategori administrasi pemerintah an, pertahanan dan jaminan sosial wajib juga kurang potensial di Kota Pekanbaru (RPs $=0,59)$, namun diwilayah Riau kategori ini sangat potensial dari sisi pertumbuhan (RPr $=1,37)$. Begitu juga dengan kategori jasa pendidikan kurang potensial di Kota Pekanbaru (RPs $=0,63)$, namun berbeda dengan di Provinsi Riau yang sangat potensial juga dari sisi pertumbuhannya $(\mathrm{RPr}=1,42)$.

Kategori jasa Kesehatan dan Sosial sangat potensial di Kota Pekanbaru (RPs = 1,37), selara dengan diwilayah Riau kategori ini sangat potensial dari sisi pertumbuhan (RPr = 2,66). Begitu juga dengan kategori jasa lainnya sangat potensial di Kota Pekanbaru (RPs $=1,74)$, sejalan dengan di Provinsi Riau yang sangat potensial juga dari sisi pertumbuhannya $(\mathrm{RPr}=3,30)$.

\subsubsection{Analisis Shift-Share Modifikasi Estaban-Marquillas}

Peningkatan kegiatan ekonomi yang diindikasikan oleh kenaikan PDRB suatu wilayah dapat diperluas (decompose) atas 3 faktor pengaruh (Syafrizal, 2002). Secara rinci ketiga faktor pengaruh tersebut adalah peningkatan PDRB yang disebabkan oleh faktor luar (kebijakan nasional/provinsi) atau sering disebut dengan efek pertumbuhan ekonomi regional (Nij). Pengaruh kedua adalah pengaruh struktur pertumbuhan kategori dan subkategori, atau disebut dengan industrial mix-effect (efek bauran industri-Mij) dan terakhir adalah pengaruh keuntungan kompetitif wilayah studi (Cij). Namun dalam perkembangannya ketiga pengaruh ini bertambah lagi, yaitu pengaruh spesialisasi perekonomian wilayah (Aij). Penambahan komponen pengaruh pertumbuhan ini telah dikembangkan oleh Estaban Marquillas (dalam Soepono, 1993) yang direpresentasikan dalam model analisis shift-share modifikasi Estaban Marquillas (Analisis SS-EM).

Tabel IV.1 memperlihatkan bahwa sejak tahun 2010 hingga 2016 terjadi peningkatan PDRB sebesar Rp16.1320 milyar di Kota Pekanbaru. Berdasarkan hasil analisis SS-EM maka kenaikan PDRB ini didominasi oleh tiga kategori ekonomi yaitu: kategori industri pengolahan yang meningkat Rp3.929 milyar, kategori konstruksi yang meningkat Rp4.350 milyar dan kategori perdagangan meningkat Rp4.443 milyar.

\section{Tabel IV.1. Hasil Analisis Shift Share Modifikasi Estaban-Marquillas Kota Pekanbaru Tahun 2010-2016 (dalam milyar rupiah)}




\begin{tabular}{|c|c|c|c|c|c|}
\hline \multirow{3}{*}{ Kategori Ekonomi } & \multirow{2}{*}{$\begin{array}{c}\text { Dampak } \\
\text { Pertumbuhan } \\
\text { Ekonomi } \\
\text { Regional }\end{array}$} & \multirow{2}{*}{$\begin{array}{c}\text { Dampak } \\
\text { Bauran } \\
\text { Industri }\end{array}$} & \multicolumn{2}{|c|}{ Cij } & \multirow{2}{*}{$\begin{array}{c}\text { Total } \\
\text { Peningkatan } \\
\text { PDRB }\end{array}$} \\
\hline & & & Competitive & Spesialisasi & \\
\hline & & (3) & & (5) & (6) \\
\hline A. Pertanian & 124 & 39 & 249 & -230 & 181 \\
\hline B. Pertambangan & 1 & -3 & 5.264 & -5.261 & 2 \\
\hline C. Industri Pengolahan & 1.469 & 1.666 & 916 & -122 & 3.929 \\
\hline D. Listrik \& gas & 15 & 28 & -2 & -7 & 34 \\
\hline E. Pengadaan Air & 2 & -1 & 0 & 0 & 0 \\
\hline F. Konstruksi & 2.038 & 2.353 & -9 & -32 & 4.350 \\
\hline G. Perdagangan & 2.004 & 2.045 & 104 & 290 & 4.443 \\
\hline H. Transportasi & 169 & 245 & 8 & 21 & 443 \\
\hline I. Akomodasi \& MakanMinum & 127 & 155 & -6 & -22 & 254 \\
\hline J. Infokom & 183 & 387 & -2 & -7 & 561 \\
\hline K. Jasa Keuangan & 229 & 349 & 48 & 156 & 781 \\
\hline L. Real Estate & 203 & 237 & 7 & 19 & 466 \\
\hline M,N. Jasa Perusahaan & 1 & 2 & 0 & 0 & 4 \\
\hline 0. Pemerintahan & 308 & 114 & -1 & -1 & 420 \\
\hline P. Jasa Pendidikan & 82 & 34 & 1 & 2 & 119 \\
\hline Q. Jasa Kesehatan \& Sosial & 29 & 48 & 5 & 10 & 92 \\
\hline R. Jasa Lainnya & 59 & 136 & 17 & 28 & 240 \\
\hline Total PDRB & 7.043 & 7.833 & 6.600 & -5.156 & 16.320 \\
\hline
\end{tabular}

Selanjutnya berdasarkan hasil analisis SS-EM, maka peningkatan PDRB di Provinsi Riau sangat dipengaruhi oleh empat faktor yaitu: dampak pertumbuhan ekonomi agregat di Indonesia (faktor eksternal) yang mampu meningkatkan agregat PDRB Provinsi Riau sebesar Rp7.043 milyar. Berdasarkan hasil analisis SS-EM maka kenaikan PDRB ini didominasi oleh tiga kategori ekonomi yaitu: kategori industri pengolahan yang meningkat Rp1.469 milyar, kategori konstruksi yang meningkat Rp2.038 milyar dan kategori perdagangan besar dan eceran, perawatan mobil dan sepeda motor sebesar Rp2.004 milyar.

Selanjutnya berdasarkan hasil analisis SS-EM, maka peningkatan PDRB di Provinsi Riau dipengaruhi lagi oleh faktor-faktor berikutnya, yaitu: dampak pertumbuhan ekonomi kategorial (industrial mix) di Indonesia yang mampu mengakibatkan pertumbuhan negatif agregat PDRB Riau sebesar Rp7.833 milyar, dampak keunggulan kompetitif (competitive advantage) yang mampu mengakibatkan pertumbuhan positif agregat PDRB Riau sebesar Rp6.600 milyar serta dampak spesialisasi perekonomian di Provinsi Riau, yang mampu mengakibatkan konstraksi/ menurunkan pertumbuhan agregat PDRB Riau sebesar Rp5.156 milyar.

\section{a. Dampak Pertumbuhan Ekonomi Indonesia terhadap Perekonom ian Provinsi Riau}

Peningkatan kegiatan ekonomi suatu daerah sangat dipengaruhi oleh kebijakan regional atau wilayah yang lebih luas (nasional/provinsi) seperti yang telah diungkapkan oleh Syafrizal (2002). Kebijakan-kebijakan ini secara langsung maupun tidak langsung akan memberikan dampak pada kinerja perekonomian daerah. Maka perkembangan perekonomian di Riau yang diindikasikan oleh laju pertumbuhan ekonomi akan berdampak bagi perkembangan perekonomian Kabupaten/Kota yang tercakup dalam wilayah Riau.

Hal ini tentu akan berpengaruh pula pada aktifitas perekonomian di Kota Pekanbaru. Dampak atau pengaruh pertumbuhan ekonomi Riau ini dapat dikatakan sebagai pengaruh yang bersumber dari luar Kota Pekanbaru (di luar kebijakan daerah), oleh karena itu pengaruh ini sering pula disebut faktor eksternal.

Tabel IV.2 memperlihatkan bahwa pengaruh kinerja perekonomian Riau, yang ditunjukkan oleh pertumbuhan ekonomi memiliki kontribusi yang besar bagi kinerja perekonomian di Kota Pekanbaru. Secara riil, pengaruh eksternal ini mampu meningkatkan PDRB Kota Pekanbaru sebesar Rp7.043 milyar. Kondisi ini menunjukkan 
bahwa 43,16 persen peningkatan PDRB (pertumbuhan ekonomi) Kota Pekanbaru disebabkan oleh pengaruh perekonomian agregat Provinsi Riau. Hal ini menunjukkan pula bahwa kinerja perekonomian Kota Pekanbaru juga dipengaruhi oleh faktor eksternal walaupun tidak signifikan.

Pengaruh perekonomian Kota Pekanbaru secara kategorial terjadi pada kategori industri pengolahan, kategori konstruksi, kategori pertambangan dan penggalian dan kategori perdagangan besar dan eceran, dan reparasi mobil dan sepeda motor. Pada kategori industri pengolahan terlihat bahwa kategori yang dipengaruhi oleh faktor eksternal sebesar 37,40 persen. Faktor eksternal ini sesungguhnya dapat meningkatkan PDRB kategori industri pengolahan, di Provinsi Riau sebesar Rp1.469 milyar, namun secara riil subkategori ini mampu meningkat Rp3.929 milyar.

Pengaruh eksternal yang besar pada kegiatan kategori konstruksi yang berdampak kepada peningkatan PDRB sehingga kategori ini dapat meningkatkan PDRB Kota Pekanbaru sebesar RP2.038 milyar, namun secara riilnya mampu meningkatkan PDRB sebesar Rp4.350 milyar.

Selanjutnya kategori yang juga banyak dipengaruhi oleh faktor eksternal adalah kategori perdagangan besar dan eceran, dan perawatan mobil dan sepeda motor. Pengaruh eksternal yang besar pada kategori ini karena dapat meningkatkan PDRB Kota Pekanbaru sebesar Rp2.004 milyar, ternyata riilnya mampu meningkatkan PDRB sebesar Rp4.443 milyar.

Secara umum, meningkatnya kondisi perekonomian Provinsi Riau dalam kurun waktu tahun 2010-2016 banyak mempengaruhi kinerja seluruh kategori ekonomi di Kota Pekanbaru. Beberapa kategori ekonomi di Kota Pekanbaru terpengaruh secara sangat signifikan, tetapi beberapa kategori atau subkategori lainnya terpengaruh tidak terlalu signifikan. Secara keseluruhan, faktor eksternal terhadap semua kategori/subkategori memberikan dampak peningkatan terhadap PDRB Kota Pekanbaru.

\section{Tabel IV.2. Dampak Pertumbuhan Ekonomi Indonesia terhadap Peningkatan PDRB Kota Pekanbaru Tahun 2010-2016 (dalam jutaan milyar dan persentase)}

\begin{tabular}{|l|r|r|r|}
\hline \multicolumn{1}{|c|}{ Kategori Ekonomi } & $\begin{array}{c}\text { Dampak } \\
\text { Pertumbuhan } \\
\text { Ekonomi } \\
\text { Regional }\end{array}$ & $\begin{array}{c}\text { Total } \\
\text { Peningkatan } \\
\text { PDRB }\end{array}$ & $\begin{array}{c}\text { Dampak } \\
\text { Faktor Luar }\end{array}$ \\
\hline A. Pertanian & (2) & (3) & \multicolumn{1}{|c|}{$(4)$} \\
\hline B. Pertambangan & 124 & 181 & 68,38 \\
\hline C. Industri Pengolahan & 1 & 2 & 87,93 \\
\hline D. Listrik \& gas & 1.469 & 3.929 & 37,40 \\
\hline E. Pengadaan Air & 15 & 34 & 44,91 \\
\hline F. Konstruksi & 2 & 0 & 539,02 \\
\hline G. Perdagangan & 2.038 & 4.350 & 46,85 \\
\hline H. Transportasi & 2.004 & 4.443 & 45,10 \\
\hline I. Akomodasi \& MakanMinum & 169 & 443 & 38,23 \\
\hline J. Infokom & 127 & 254 & 50,07 \\
\hline K. Jasa Keuangan & 183 & 561 & 32,57 \\
\hline L. Real Estate & 229 & 781 & 29,26 \\
\hline M,N. Jasa Perusahaan & 203 & 466 & 43,53 \\
\hline O. Pemerintahan & 1 & 4 & 28,38 \\
\hline P. Jasa Pendidikan & 308 & 420 & 73,26 \\
\hline Q. Jasa Kesehatan \& Sosial & 82 & 119 & 68,60 \\
\hline R. Jasa Lainnya & 29 & 92 & 31,43 \\
\hline \multicolumn{1}{|c|}{ Total PDRB } & 59 & 240 & 24,62 \\
\hline & 7.043 & 16.320 & 43,16 \\
\hline
\end{tabular}

b. Dampak Bauran Industri di Provinsi Riau terhadap Perekonomian Kota
Pekanbaru
Dampak bauran industri (industrial mix-effect) atau struktur pertumbuhan 
ekonomi di Riau berpengaruh positif terhadap peningkatan PDRB di Kota Pekanbaru seperti yang terlihat pada Tabel 4.3. Hasil analisis menunjukkan bahwa bauran industri memberikan pengaruh yang positif bagi perkembangan perekonomian Kota Pekanbaru, yaitu sebesar Rp7.833 milyar atau sebesar 48 persen. Nilai positif mengindikasikan bahwa komposisi kategori pada PDRB Kota Pekanbaru cenderung mengarah pada perekonomian yang tumbuh cepat.

Dampak positif bauran industri menunjukan bahwa struktur pertumbuhan ekonomi di Riau justru mempercepat pertumbuhan perekonomian di Kota Pekanbaru sebesar 48 persen. Namun pengaruh ini sedikit lebih besar jika dibandingkan dengan dampak pertumbuhan ekonomi agregat Riau yang mampu mempengaruhi peningkatan kinerja perekonomian Kota Pekanbaru sebesar 43,16 persen.

Secara keseluruhan, kategori-kategori ekonomi PDRB di Provinsi Riau dipengaruhi secara positif lebih besar oleh struktur pertumbuhan ekonomi Riau yaitu kategori ekonomi Provinsi Riau yang paling besar memperoleh imbas negatif dari nasional adalah kategori industri pengolahan yang meningkatkan PDRB Kota Pekanbaru sebesar Rp1.666 milyar. Kategori berikutnya yang mendapatkan imbas positif dari struktur pertumbuhan ekonomi Riau adalah kategori konstruksi terhadap PDRB Kota Pekanbaru sebesar Rp2.353 milyar. Kemudian kategori yang memperoleh imbas postif dari dampak bauran industri ini adalah kategori perdagangan besar dan eceran, perawatan mobil dan sepeda motor yang meningkatkan PDRB Provinsi Kota Pekanbaru sebesar Rp2.045 milyar.

Tabel IV.3. Dampak Pertumbuhan Ekonomi Kategorial Provinsi Riau (Industrial Mix Effect) terhadap Peningkatan PDRB Kota Pekanbaru Tahun 2010-2016 (dalam milyar rupiah dan persentase)

\begin{tabular}{|l|r|r|r|}
\hline \multicolumn{1}{|c|}{ Kategori Ekonomi } & $\begin{array}{c}\text { Dampak } \\
\text { Bauran } \\
\text { Industri }\end{array}$ & $\begin{array}{c}\text { Total } \\
\text { Peningkatan } \\
\text { PDRB }\end{array}$ & $\begin{array}{c}\text { Pengaruh } \\
\text { Dampak } \\
\text { Industrial } \\
\text { Mix }\end{array}$ \\
\hline A. Pertanian & $(2)$ & $(3)$ & \multicolumn{1}{|c|}{$(4)$} \\
\hline B. Pertambangan & 39 & 181 & 21,31 \\
\hline C. Industri Pengolahan & -3 & 2 & $-189,40$ \\
\hline D. Listrik \& gas & 1.666 & 3.929 & 42,40 \\
\hline E. Pengadaan Air & 28 & 34 & 80,41 \\
\hline F. Konstruksi & -1 & 0 & $-356,09$ \\
\hline G. Perdagangan & 2.353 & 4.350 & 54,10 \\
\hline H. Transportasi & 2.045 & 4.443 & 46,03 \\
\hline I. Akomodasi \& MakanMinum & 245 & 443 & 55,30 \\
\hline J. Infokom & 155 & 254 & 60,88 \\
\hline K. Jasa Keuangan & 387 & 561 & 69,01 \\
\hline L. Real Estate & 349 & 781 & 44,64 \\
\hline M,N. Jasa Perusahaan & 237 & 466 & 50,97 \\
\hline O. Pemerintahan & 2 & 4 & 58,42 \\
\hline P. Jasa Pendidikan & 114 & 420 & 27,07 \\
\hline Q. Jasa Kesehatan \& Sosial & 34 & 119 & 28,87 \\
\hline R. Jasa Lainnya & 48 & 92 & 52,11 \\
\hline Total PDRB & 136 & 240 & 56,59 \\
\hline & 7.833 & 16.320 & 48,00 \\
\hline & & & \\
\hline
\end{tabular}

Namun, ada juga beberapa kategori yang mendapatkan imbas negatif dari struktur pertumbuhan ekonomi Riau yaitu kategori pertambangan dan penggalian yaitu mendapatkan imbas positif sebesar Rp3 milyar terhadap PDRB Provinsi Kota Pekanbaru. Selanjutnya kategori pengadaan air dan gas juga mendapatkan imbas negatif dari pengaruh struktur pertumbuhan ekonomi Riau yaitu sebesar Rp1 milyar terhadap PDRB Kota Pekanbaru.

\section{c. Dampak Keunggulan Kompetitif Spesialisasi}


Analisis Shift Share Esteban Marquillas dapat mendeteksi kategori dan subkategori ekonomi yang memiliki keunggulan kompetitif dan spesialisasi pada suatu wilayah. Kategori ekonomi dikatakan memiliki keunggulan kompetitif sekaligus spesialisasi jika pertumbuhan dan peranannya lebih baik dibandingkan dengan pertumbuh an dan peranan kategori yang sama dalam perekonomian Provinsi Riau.

Tabel IV.4 menunjukkan bahwa ada delapan kategori ekonomi yang mempunyai keunggulan kompetitif dan spesialisasi di Kota Pekanbaru yaitu kategori perdagangan besar dan eceran, perawatan mobil dan sepeda motor, kategori transportasi dan pergudangan, kategori jasa keuangan, kategori real estate, kategori jasa perusahaan, kategori jasa pendidikan, kategori jasa kesehatan dan sosial dan kategori jasa lainnya.

Dari Tabel IV.5 tampak bahwa dampak keunggulan kompetitif terhadap peningkatan PDRB Provinsi Riau dipengaruhi kategori pertambangan dan penggalian (sebesar 314.590 persen), kategori pertanian (sebesar 137 persen), kategori industri pengolahan (sebesar 23,31 persen) dan kategori jasa lainnya (sebesar 7,29 persen).

Adapun dampak spesialisasi terhadap peningkatan PDRB Provinsi Riau dipengaruhi oleh kategori jasa keuangan (sebesar 19,96 persen) yang memberikan sumbangan terhadap peningkatan PDRB sebesar 156 milyar. Kategori jasa lainnya juga memberikan sumbangan yang cukup signifikan terhadap peningkatan PDRB Provinsi Riau yaitu sebesar Rp28 milyar, namun dampaknya cukup kecil hanya 11,51 persen saja. Tabel IV.4. Identifikasi Keunggulan Kompetitif dan Spesialisasi Perekonomian Kota Pekanbaru Tahun 2010-2016

\begin{tabular}{|c|c|c|c|c|}
\hline \multirow{2}{*}{ Kategori Ekonomi } & \multirow{2}{*}{ rij-rin } & \multirow{2}{*}{$E j-E^{* i j}$} & \multicolumn{2}{|c|}{ Ada/Tidak } \\
\hline & & & $\begin{array}{l}\text { Keunggulan } \\
\text { Komparatif }\end{array}$ & Spesialisasi \\
\hline (1) & (2) & (3) & & (5) \\
\hline A. Pertanian & 0,03 & -9.048 & ada & tidak \\
\hline B. Pertambangan & 0,39 & -13.595 & ada & tidak \\
\hline C. Industri Pengolahan & 0,09 & -1.338 & ada & tidak \\
\hline D. Listrik \& gas & $-0,10$ & 73 & tidak & ada \\
\hline E. Pengadaan Air & $-0,03$ & 5 & tidak & ada \\
\hline F. Konstruksi & 0,00 & 9.341 & tidak & ada \\
\hline G. Perdagangan & 0,03 & 8.730 & ada & ada \\
\hline H. Transportasi & 0,03 & 724 & ada & ada \\
\hline I. Akomodasi \& MakanMinum & $-0,04$ & 598 & tidak & ada \\
\hline J. Infokom & $-0,01$ & 831 & tidak & ada \\
\hline K. Jasa Keuangan & 0,15 & 1.035 & ada & ada \\
\hline L. Real Estate & 0,02 & 894 & ada & ada \\
\hline M,N. Jasa Perusahaan & 0,08 & 5 & ada & ada \\
\hline O. Pemerintahan & 0,00 & 1.121 & tidak & ada \\
\hline P. Jasa Pendidikan & 0,01 & 297 & ada & ada \\
\hline Q. Jasa Kesehatan \& Sosial & 0,09 & 114 & ada & ada \\
\hline R. Jasa Lainnya & 0,13 & 214 & ada & ada \\
\hline
\end{tabular}

Tabel IV.5. Dampak Keunggulan Kompetitif dan Spesialisasi Terhadap Peningkatan PDRB Kota Pekanbaru Tahun 2010-2016 (dalam milyar rupiah dan persentase)

Dengan teridentifikasinya spesia lisasi perekonomian di Kota Pekanbaru, maka dampak alokasi yang direpresentasikan pada Tabel IV.5 dapat digunakan untuk mengetahui besaran pengaruh dampak alokasi terhadap peningkatan PDRB di Kota Pekanbaru. Tabel |IV.5 tersebut memperlihatkan bahwa kategori jasa keuangan memiliki dampak alokasi cukup besar (Rp156 milyar), dengan mempertimbangkan Tabel IV.4, maka kategori tersebut juga memiliki keunggulan kompetitif dan spesialisasi di Kota Pekanbaru. 


\subsubsection{Analisis Overlay}

Analisis overlay merupakan analisis yang digunakan untuk melihat kategori ekonomi potensial baik dari sisi kontribusi maupun dari sisi pertumbuhan PDRB. Dalam penelitian ini, analisis overlay juga merupakan bahan perbandingan berbagai alat analisis yang digunakan untuk melihat kategori dan subkategori ekonomi potensial di Kota Pekanbaru.

Untuk melihat potensi ekonomi Kota Pekanbaru secara lebih komprehensif, maka analisis overlay dilakukan dengan pertimbangan memasukkan hasil analisis SS-EM, sehingga analisis overlay yang dipergunakan untuk melihat keunggulan dan potensi ekonomi di Kota Pekanbaru ini merupakan integrasi antara analisis $L Q$ (aspek keunggulan komparatif), analisis MRP (Rasio Pertumbuhan Wilayah Studi-RPs) dan analisis SS-EM (aspek spesialisasi dan keunggulan kompetitif).

Tabel IV.6 menunjukkan bahwa berdasarkan analisis overlay diperoleh lima kategori ekonomi yang potensial di Kota Pekanbaru yaitu kategori transportasi dan pergudangan, kategori jasa keuangan, kategori jasa perusahaan, kategori jasa kesehatan dan sosial dan kategori jasa lainnya. Potensi yang besar dari kategori tersebut karena dari berbagai alat analisis yang digunakan menunjukkan bahwa kategori ekonomi ini memiliki keunggulan komparatif, keunggulan kompetitif, spesialisasi sekaligus memiliki rasio pertumbuhan yang baik jika dibandingkan dengan perekonomian Provinsi Riau.

\section{Tabel IV.6. Analisis Overlay Potensi Ekonomi Kota Pekanbaru Tahun 2010-2016}

\begin{tabular}{|c|c|c|c|c|}
\hline Kategori Ekonomi & $\begin{array}{l}\text { Dampak } \\
\text { Keunggulan } \\
\text { Kompetitif }\end{array}$ & Dampak Alokasi & \begin{tabular}{|c|} 
Pengaruh \\
Dampak \\
Keunggulan \\
Kompetitif
\end{tabular} & $\begin{array}{l}\text { Pengaruh } \\
\text { Dampak } \\
\text { Alokasi }\end{array}$ \\
\hline (1) & (2) & (3) & (4) & (5) \\
\hline A. Pertanian & 249 & -230 & 137,33 & $-127,02$ \\
\hline B. Pertambangan & 5.264 & -5.261 & $314.590,28$ & $-314.388,81$ \\
\hline C. Industri Pengolahan & 916 & -122 & 23,31 & $-3,11$ \\
\hline D. Listrik \& gas & -2 & -7 & $-5,15$ & $-20,16$ \\
\hline E. Pengadaan Air & 0 & 0 & $-46,65$ & $-36,29$ \\
\hline F. Konstruksi & -9 & -32 & $-0,21$ & $-0,73$ \\
\hline G. Perdagangan & 104 & 290 & 2,34 & 6,52 \\
\hline H. Transportasi & 8 & 21 & 1,81 & 4,67 \\
\hline I. Akomodasi \& MakanMinum & -6 & -22 & $-2,26$ & $-8,69$ \\
\hline J. Infokom & -2 & -7 & $-0,37$ & $-1,21$ \\
\hline K. Jasa Keuangan & 48 & 156 & 6,14 & 19,96 \\
\hline L. Real Estate & 7 & 19 & 1,41 & 4,09 \\
\hline M,N. Jasa Perusahaan & 0 & 0 & 3,19 & 10,01 \\
\hline 0. Pemerintahan & -1 & -1 & $-0,13$ & $-0,20$ \\
\hline P. Jasa Pendidikan & 1 & 2 & 0,97 & 1,56 \\
\hline Q. Jasa Kesehatan \& Sosial & 5 & 10 & 5,51 & 10,95 \\
\hline R. Jasa Lainnya & 17 & 28 & 7,29 & 11,51 \\
\hline Total PDRB & 6.600 & -5.156 & 40,44 & $-31,59$ \\
\hline
\end{tabular}

\begin{tabular}{|c|c|c|c|c|c|c|c|c|}
\hline \multirow[t]{2}{*}{ Kategori Ekonomi } & & LQ & \multicolumn{2}{|c|}{ Analisis SS-EM } & \multicolumn{4}{|c|}{ Overlay } \\
\hline & "MRP" & & rij-rin & $\mathrm{E} \mid \mathrm{E}-\mathrm{Ei} \mathrm{i}^{\mathrm{2}}$ & & & & \\
\hline (1) & (2) & (3) & (4) & (5) & (6) & (7) & (8) & \\
\hline A. Pertanian & 0,63 & 0,08 & 0,03 & -9.048 & - & - & + & . \\
\hline B. Pertambangan & 0,49 & 0,00 & 0,39 & -13.595 & - & - & + & - \\
\hline C. Industri Pengolahan & 1,15 & 0,91 & 0,09 & -1.338 & + & - & + & $\cdot$ \\
\hline D. Listrik \& gas & 0,96 & 4,69 & $-0,10$ & 73 & - & + & - & + \\
\hline E. Pengadaan Air & 0,08 & 1,71 & $-0,03$ & 5 & . & + & - & + \\
\hline F. Konstruksi & 0,92 & 4,30 & 0,00 & 9.341 & . & + & - & + \\
\hline G. Perdagangan & 0,95 & 3,84 & 0,03 & 8.730 & . & + & + & + \\
\hline H. Transportasi & 1,12 & 3,64 & 0,03 & 724 & + & + & + & + \\
\hline l. Akomodasi \& MakanMinum & 0,86 & 4,93 & $-0,04$ & 598 & - & + & - & + \\
\hline J. Infokom & 1,32 & 4,13 & $-0,01$ & 831 & + & + & . & + \\
\hline K. Jasa Keuangan & 1,47 & 4,42 & 0,15 & 1.035 & + & + & + & + \\
\hline L. Real Estate & 0,99 & 3,96 & 0,02 & 894 & - & + & + & + \\
\hline M,N. Jasa Perusahaan & 1,51 & 4,21 & 0,08 & 5 & + & + & + & + \\
\hline 0. Pemerintahan & 0,59 & 2,54 & 0,00 & 1.121 & - & + & - & + \\
\hline P. Jasa Pendidikan & 0,63 & 2,59 & 0,01 & 297 & - & + & + & + \\
\hline Q. Jasa Kesehatan \& Sosial & 1,37 & 3,09 & 0,09 & 114 & + & + & + & + \\
\hline R. Jasa Lainnya & 1,74 & 2,62 & 0,13 & 214 & + & + & + & + \\
\hline
\end{tabular}

Keterangan dari tabel di atas:

1. Jika nilai MRP atau $L Q>1$, maka tandanya + yang berarti kategori/subkategori ini potensial

2. Jika nilai MRP atau $L Q<1$, maka tandanya - yang berarti kategori/subkategori ini tidak berpotensial

3. Jika nilai (rij-rin) atau (Eij-Eij*) $>1$, maka tandanya + yang berarti kategori/subkategori ini potensial

4. Jika nilai (rij-rin) atau (Eij-Eij $\left.{ }^{*}\right)<1$, maka tandanya - yang berarti kategori/subkategori ini tidak berpotensial. 


\subsection{Analisis Pola dan Struktur Pertumbuhan Ekonomi Kota Pekanbaru}

Tipologi klassen juga dapat digunakan untuk melihat pola dan struktur pertumbuhan ekonomi secara kategori. Dengan modifikasi tipologi klassen dapat diklasifikasikan kategori ekonomi di suatu daerah (region). Klasifikasi kategori ekonomi di Kota Pekanbaru berdasarkan tipologi klassen adalah:

1. Kategori yang maju dan cepat tumbuh, yaitu kategori yang memiliki laju pertumbuhan dan kontribusinya lebih tinggi dibandingkan dengan laju pertumbuhan dan kontribusi kategori tersebut secara keseluruhan di Provinsi Riau. Kategori yang termasuk klasifikasi ini adalah kategori perdagangan besar dan eceran, perawatan mobil dan sepeda motor, kategori transportasi dan pergudangan, kategori jasa keuangan, kategori real estate,kategori jasa perusahaan, kategori jasa pendidikan, kategori jasa kesehatan dan sosial dan kategori jasa lainnya.

2. Kategori yang maju tapi tertekan, yaitu kategori yang laju pertumbuhannya lebih kecil dari laju pertumbuhan kategori di Provinsi Riau, akan tetapi kontribusi kategori tersebut lebih besar dari kontribusi kategori di Provinsi Riau. Kategori ekonomi yang termasuk dalam klasifikasi ini adalah kategori listrik dan gas, kategori pengadaan air, kategori konstruksi, kategori akomodasi dan makan minum, kategori informasi dan komunikasi dan kategori administrasi pemerintahan, pertahanan dan jaminan sosial wajib.

3. Kategori yang berkembang cepat, yaitu kategori yang laju pertumbuhannya lebih besar dibandingkan dengan laju pertumbuhan kategori di Provinsi Riau, akan tetapi kontribusi kategori tersebut lebih rendah dari kontribusi kategori di Provinsi Riau. Kategori yang termasuk klasifikasi ini adalah kategori pertanian, kehutanan dan perikanan, kategori pertambangan dan penggalian dan kategori industri pengolahan. 4. Kategori yang relatif tertinggal, yaitu kategori yang memiliki laju pertumbuhan dan kontribusinya lebih rendah dari laju pertumbuhan dan kontribusi kategori tersebut di Provinsi Riau. Kategori yang termasuk dalam klasifikasi ini tidak ada (selengkapnya lihat Tabel IV.7).

Tabel IV.7 Klasifikasi Sektor/ Subsektor Ekonomi Menu rut Tipologi Klassen di Kota Pekanbaru Tahun 2010-2016 


\begin{tabular}{|c|c|c|c|c|c|}
\hline \multirow{2}{*}{ Kategori } & \multicolumn{2}{|c|}{ Kota Peknanberu } & \multicolumn{2}{|c|}{ Provinsi Rilau } & \multirow{2}{*}{ Keterangan } \\
\hline & Kontibusi & Pertunbuhan & Kontibusis & Pertumbuhar & \\
\hline (1) & (2) & (3) & (4) & (5) & (6) \\
\hline A. Perlanian & 1,66 & 4,12 & 21,0 & 3,69 & Berkembang Cepat \\
\hline B. Pertambangan & 0,02 & 3,20 & 36,3 & $-3,25$ & Berkembang Cepat \\
\hline C. Indussi Penogalahan & 20,22 & 7,53 & 22,3 & 6,01 & Berkembang Cepat \\
\hline D. Listik \& gas & 0,18 & 6,27 & 0,0 & 7,85 & Maju tapi tertekan \\
\hline E. Pengadban Air & 0,02 & 0,52 & 0,0 & 0,96 & Maju bapi tertekan \\
\hline F. Konstuksi & 29,37 & 6,01 & 6,9 & 6,07 & Maju tapi tertekan \\
\hline G. Perclagangan & 29,01 & 6,24 & 7,0 & & Majud dan Cepat Tumbuh \\
\hline H. Transpotasi & 2,44 & 7,36 & 0,0 & & Majud dan Cepat Tumbuh \\
\hline 1. Akomodasi \& Makann Minum & 2,06 & 5,02 & 0,4 & 6,24 & Maju lapi itrektan \\
\hline J hrokom & 2,32 & 8,64 & 0,5 & 8,78 & Maju api tertekan \\
\hline K. Jasa Keluangan & 3,53 & 9,62 & 0,8 & & Maju dan Cepat Tumbuh \\
\hline L. Real Essate & 2,87 & 6,47 & 0,7 & & Majud dan Cepat Tumbuh \\
\hline M,N. Jasa Pervsahaan & 0,02 & 9,92 & 0,0 & & Majud dan Cepat Tumbuh \\
\hline 0. Pemeninhahan & 3,81 & 3,84 & 1,5 & 3,85 & Maju tapi tertekan \\
\hline P. Jasa Pendidikan & 1,11 & 4,10 & 0,4 & & Majud dan Cepat Tumbuh \\
\hline Q. Jasa Kesechatan \& Sosial & 0,45 & 8,96 & 0,1 & & Maju dan Cepat Tumbuh \\
\hline R.Jasa Lainnya & 0,92 & 11,43 & 0,3 & & Majud dan Cepat Tumbuh \\
\hline
\end{tabular}

\subsection{Kesimpulan}

\section{KESIMPULAN DAN SARAN}

Berdasarkan hasil analisis diatas maka dapat di simpulkan potensi investasi dan produk unggulan yang dimiliki kota Pekanbaru berdasarkan data olahan yang didasarkan pada PDRB Kota pekanbaru, analisis Overlay ( Integrasi antara metode Location Quotient (LQ),MRP dan Shift Share (SS)) dan tipology Klessen dapat diketahui subsektor ekonomi yang pontesial di kembangkan di kota pekanbaru adalah sebagai berikut:

1) Kategori Perdagangan dan reparasi,

2) Kategori jasa Transportasi,

3) Kategori jasa Perusahaan,

4) Kategori jasa kesehatan dan sosial dan

5) Kategori jasa lainnya.

\subsection{Saran}

Mengingat Kota Pekanbaru merupakan salah satu kota metroplitan yang ada di wilayah sumatera, dan untuk dapat menarik lebih banyak lagi para investor agar mau menanamkan sejumlah investasinya di Kota Pekanbaru maka diperlukan sebuah terobosan dan inovasi dalam hal Birokrasi Perijinan, ketersediaan infrastruktur yang bagus dalam menunjang semua lini bisnis dan insentif bagi para pelaku bisnis baik dari sisi pajak maupun non Pajak seperti rasa aman dan kepastian hukum dalam berinvestasi.

\section{Daftar Pustaka}

Aprilianto DP (2003). Identifikasi Potensi Ekonomi Kota Pekalongan. Jurnal Ekonomi dan Bisnis, Vol 1. No.1 Maret 2003. 24-38. FE Unikal, Pekalongan. 
Sumitro Djojohadikusumo. (1995). Perkembangan Pemikiran Ekonomi Dasar Teori Pertumbuhan dan Ekonomi Pembangunan. Jakarta

Jhingan, M.L., (2003). Ekonomi Pembangunan dan Perekonomian. Jakarta : PT. Raya Grafindo Persada.

Parulian, A. (2009). Monitoring dan Analisis Kadar Aluminium (Al) dan Besi (Fe) Pada Pengolahan Air Minum PDAM Tirtanadi Sunggal. Tesis, tidak dipublikasikan, Universitas Sumatera Utara: Medan.

Peraturan Pemerintah, undang-undang (UU) Nomor 22 tahun 1999 tentang Pemerintahan Daerah

Peraturan Pemerintah, UU Nomor 25 Tahun 1999 tentang Perimbangan Keuangan antara Pemerintah Pusat dan Pemerintah Daerah

Ivan Budi Yuwono. (1999). Pengaruh Komitmen Organisasi dan Ketidakpastian Lingkungan Terhadap Hubungan antara Partisipasi Anggaran dengan Senjangan Anggaran. Jurnal Bisnis dan Akuntansi, volume 1, No. 1, April 1999, hal 37 - 55.

Sjafrizal. (2008). Ekonomi Regional, Teori dan Aplikasi. Baduose Media. Cetakan Pertama. Padang.

Sukirno, Sadono. (2004). Pengantar Teori Makroekonomi. Jakarta: PT Raja Grafindo Persada.

Peraturan Pemerintah No.26 Tahun 2008 tentang Rencana Tata Ruang Wilayah Nasional Glasson, John. (1990). Pengantar Perencanaan Regional (An Introduction to Regional Planing). terjemahan Paul Sitohang. Jakarta. FE-UI

Arsyad,Azhar. (2008). Media Pembelaja ran. Jakarta: PT Raya Grafindo Persada

Tarigan. (2003). Faktor-faktor yang berhubungan dengan Status Gizi Anak Umur 3-36 bulan sebelum dan saat Krisis Ekonomi di Jawa Tengah. Buletin Penelitian Kesehatan Depkes RI. Vol. 31. No.1. hal. 1-12

Miftah Thoha.(2003). Perilaku Organisasi, Edisi Pertama, Cetakan Keempat belas, PT Raja Grafindo Persada, Jakarta.

Muzamil, MA. (2010). Dampak Limbah Cair Pabrik Tekstil PT Kenaria Terhadap Kualitas Air Sungai Winong Sebagai Irigasi Pertanian di Desa Purwosuman Kecamatan Sidoharjo Kabupaten Sragen. Skripsi. Surakarta : Fakultas Keguruan Dan Ilmu Pendidikan Universitas Sebelas Maret Surakarta.

Soepono, Prasetyo. (1993). Analisis Shift-share: Perkembangan dan Penerap an. Jurnal Ekonomi dan Bisnis Indonesia, volume 8 nomor 1.Yogyakarta. Fakultas Ekonomi UGM

Hairul Aswandi dan Mudrajat Kuncoro (2002). Evaluasi Penetapan Kawasan Andalan:Studi Empiris di Kalimantan Selatan 1993-1999. Jurnal Ekonomi dan Bisnis Indonesia. Vol. 17. No 1. 2002.

Thoha, Mahmud dan Soekarni, M. (2000). Studi Kelayakan Ekonomi Pembentukan Propinsi Baru: Kasus Banten. Jurnal Ekonomi dan Pembangunan (JEP). VIII 2000.

Rangkuti, Freddy. (2001). Analisis SWOT Teknik Membelah Kasus Bisnis. PT. Gramedia Pustaka Utama. Jakarta.

Esteban-Marquillas, J.M. (1972). A reinterpretations in extending shift-share analysis. Regional and Urban Economics, 23:249-55. 
